\title{
Paideusis
}

\section{Following the Argument: A Philosophical Memoir}

\section{William Hare}

Volume 19, Number 2, 2010

URI: https://id.erudit.org/iderudit/1071924ar

DOI: https://doi.org/10.7202/1071924ar

See table of contents

Publisher(s)

Canadian Philosophy of Education Society

ISSN

0838-4517 (print)

1916-0348 (digital)

Explore this journal

Cite this document

Hare, W. (2010). Following the Argument: A Philosophical Memoir. Paideusis, 19(2), 78-85. https://doi.org/10.7202/1071924ar

This document is protected by copyright law. Use of the services of Erudit (including reproduction) is subject to its terms and conditions, which can be viewed online.

https://apropos.erudit.org/en/users/policy-on-use/
This article is disseminated and preserved by Érudit.

Érudit is a non-profit inter-university consortium of the Université de Montréal, Université Laval, and the Université du Québec à Montréal. Its mission is to promote and disseminate research.

https://www.erudit.org/en/ 


\title{
Following the Argument: A Philosophical Memoir
}

\author{
WILLIAM HARE \\ Mount Saint Vincent University
}

I was in the right place at the right time. Canadian universities were in an expansionist mood in the 1960s and business was brisk with respect to hiring. It was in full swing when I entered the Ph.D. program at the Ontario Institute for Studies in Education in 1968 and, fortunately for me, had not quite petered out by the time my two-year residency was drawing to a close. The Department of Education at Dalhousie University was in the midst of reorganizing its B.Ed. program in 1969-1970 with a new emphasis on introducing student teachers to what had come to be regarded as the main disciplines relevant to educational theory, one of which was philosophy of education. The position at Dalhousie also involved a minor appointment in the Department of Philosophy and this made it all the more attractive. I interviewed successfully in January 1970, and so it was that in August that year, Niki and I arrived in Halifax where we have made our home now for forty years. Within a few months, I had defended my dissertation and my career was well underway.

All this lay in the unknown future and could scarcely have been imagined when I was growing up in post-war Britain. My parents came to England from Ireland just before the Second World War and settled in Leicester. I was the second of six children in a working class, Irish Catholic family living in austere conditions exacerbated by rationing and general shortages. Neither of my parents had the opportunity to continue their schooling beyond the age of fifteen and consequently never tired of reminding us of the importance of education. I had excellent teachers at elementary school (fond memories here of Sister Gemma) and this played a large part in my being successful at the so-called $11+$ examination. My good fortune increased when I was offered a place at Wyggeston Boys, widely regarded as the leading Grammar School in Leicester. I was at Wyggeston from 1955 to 1962.

Early specialization was the order of the day and I quickly gravitated towards the arts stream. History was my favourite subject and once again the gods were smiling on me. For five of the seven years I spent at Wyggeston, I studied history with E.G. Rayner, certainly the teacher to whom I am most indebted. He stood out from the crowd because of his wit, infectious enthusiasm, and scholarship, and was one of the few teachers to grasp instinctively the need for students to develop a critical perspective. The qualities that made him such an excellent teacher are very much in evidence in his recent work in popular history. ${ }^{1}$ Whether or not he had read Dewey, he understood (where most did not) the importance of student interest and curiosity and would have entirely agreed with Dewey's strictures on the mere amassing of information. It was in his classes, too, that I learned most about essay writing. Essays were frequently set, especially in the later years, and each assignment was carefully worded so as to require one to examine an interpretation or opinion and to defend one's own position. Evidence was to be weighed, each side given due attention, and one's conclusions supported. Follow

\footnotetext{
${ }^{1}$ Ed Rayner and Ron Stapley. Debunking History: 151 Popular Myths Exploded. Stroud, UK: Sutton Publishing, 2002.

(C) Copyright 2010. The author, William Hare, assigns to Paideusis the right of first publication and educational and non-profit institutions a non-exclusive license to use this document for personal use and in courses of instruction provided that the article is used in full and this copyright statement is reproduced. Any other usage is probibited without the express permission of the author.
} 
the argument! Without realizing it, I was receiving an education in critical and independent thinking. I was astounded to hear from a number of students in my Introductory Philosophy course at Dalhousie University that they had never written an essay of any kind at school.

There was no sign of philosophy on the timetable at Wyggeston and there were few references to philosophy in other subjects. I only learned much later that the distinguished philosopher, A.C. Ewing, was a former pupil. An interest in philosophical ideas and problems evidently emerged, however, even if I could not have named it as such. In my final year at Wyggeston, quite out of the blue, one of my teachers handed me a neatly typed list of ten or so philosophy titles, mainly historical, with one or two recent books including The Problem of Knowledge, by A.J. Ayer, published in 1956. What prompted this I am not sure-perhaps comments I had made or questions I had raised. I could see at once on reading Ayer that these were indeed the sort of questions I was very interested in and it suddenly became clear to me that I had been thinking about philosophical issues for some time.

In particular, I had thought a great deal about ethical issues beginning with the controversy over the execution of Derek Bentley in 1953. I knew from adult conversation that many people thought his trial was seriously flawed (as subsequent reviews were to establish) and I had a first glimmering of the notion that the law might get things wrong. There was a great deal of controversy in the 1950s around censorship, capital punishment, nuclear disarmament, and other issues, and I was not only interested in these debates in themselves but also in the more general question of how such contentious matters could be resolved. On another front, I was aware that there were 'proofs' of God's existence and I had some idea what these arguments involved. I wondered how good they were and how they compared with proofs that we had met in geometry and science. On political matters, it was not difficult to see that much of what was presented in the media with respect to British involvement overseas was mere propaganda. 'Murder mile', for example, hardly seemed a neutral description and I had a strong suspicion that that was not the way Cypriots referred to Ledra Street. Such thoughts led me to an interest in bias and prejudice and the need to think for oneself.

My first inkling of philosophical issues in education came in 1959 when C.P. Snow (also from Leicester) gave his widely discussed Rede lecture on 'The two cultures', a division brought home to me a year later when I learned that, as an arts student, the school timetable would not permit me to study mathematics in the sixth form. The seeds of my later interest in philosophy of education may have been sown at this time. Meanwhile, I left school in 1962 to pursue a degree in history, literature, and philosophy, graduating with a B.A. from the University of London in 1965. It was in London that I met Niki who had come to England from Cyprus to study. We were married in 1966. She has given me all the support and encouragement I have ever needed throughout our life together.

My love of history remained strong (not surprisingly, given that I had the good fortune to take courses in London with Colin Tite), but it was clear by the time I graduated that my central interests were in philosophy. My background at this point was not adequate to begin graduate studies, but John Kemp, Professor of Philosophy at the University of Leicester, suggested a way forward. Under his guidance, I studied for a further year, concentrating on ethics, epistemology, and philosophy of mind, and sat for a series of examinations at the end of the year. Deeming my performance "very creditable", he admitted me to a two-year M.A. program in Philosophy in 1966.

Roy Holland became my supervisor, and my weekly tutorials with him consisted of discussions of books and articles he had assigned (Simone Weil, Elizabeth Anscombe, Philippa Foot, Wittgenstein, and John Wisdom were high on the list), alternating with sessions in which he would react, kindly but critically, to essays I had written on various topics. These occasions were a wonderful opportunity to learn from a gifted philosopher and teacher. I also sat in on Jim Gribble's course in philosophy of education for student teachers at the School of Education at the University of Leicester and this opened my eyes to the exciting work emerging in this field spearheaded in the U.K. by R.S. Peters. At the end of my first year, Roy Holland took up a Chair in Philosophy at the University of Leeds, and my M.A. thesis was very capably supervised by Roger Montague and examined by Alan R. White. 
I had decided that I would concentrate on philosophy of education for my Ph.D. and I was awarded a two-year graduate fellowship at the Ontario Institute for Studies in Education (OISE). Having cleared the various immigration hurdles, Niki and I set off for Canada in August 1968. I wrote my doctoral thesis on what it means to have a sense of responsibility, together with reflections on education for responsible action. The philosopher I most admired at the University of Toronto was D.P. Dryer with whom I studied social philosophy, concentrating on the work of Rawls. Dryer had a reputation as an intimidating instructor, but I found him to be unfailingly kind and supportive. He was meticulous in examining arguments, and utterly fair-minded in setting out views he disagreed with. I was honoured when he agreed to serve on my thesis committee.

A memorable event during my time in Toronto was the "New directions in philosophy of education" conference held in April 1970. Here I had the pleasure of meeting many of the leading philosophers of education in the United States whose work I had come to admire, especially Israel Scheffler, Jane Roland Martin, and Jonas Soltis. I was particularly interested in Scheffler's work, having come to think of The Language of Education (1960) and Conditions of Knowledge (1978) as epitomizing what R.M. Hare had deemed essential for first-rate work in philosophy of education - that it must address itself to an important problem in education and be carried out by a competent philosopher with a serious interest in the topic. It was a privilege many years later to be invited to contribute an article (1997) to a collection, edited by Harvey Siegel, dedicated to Scheffler's achievement. In addition to Scheffler, I have been greatly influenced by John Passmore and R.M. Hare. The clarity and cogency of argument in the writings of these three philosophers represented to me what philosophy of education at its best could be. I paid tribute to R.M. Hare (2001) and John Passmore (2005) when they passed away, and tried to bring out what makes their work so valuable.

No sooner had I arrived at Dalhousie University in 1970 than I received an invitation from the Canada Studies Foundation to write a paper on the aims of education in a multicultural society, subsequently published (1972). I argued for a number of aims in the context of cultural diversity, including the development of critical ability and open-mindedness. I had hit upon the topic that was to become the main research project throughout my career and I had done so at the very outset. Thinking back now to the origins of my interest in open-mindedness, I am struck by the fact that Scheffler's paper at the 1970 conference was a powerful critique of the fanaticism and dogmatism that was mounting an attack on philosophy and intellectual pursuits during that period. It was a short step from reflections on fanaticism and dogmatism to an examination of the positive ideal of open-mindedness, and I have been following up this insight ever since.

I remain deeply grateful for the helpful advice and encouragement I received in those early days, especially from my colleague, David Braybrooke, and from Jonas Soltis and Alan White, as I began to write and publish papers on such topics as controversial issues (1973), discussion methods (1974), and critical listening (1975). These articles helped to bring into focus my growing interest in openmindedness as an aim of education, and I had an opportunity to try out some preliminary ideas on the theme of 'openness' in education at the 1974 Philosophy of Education (PES) Conference in Boston (1974). (The turnout for my paper was modest, but it did include Harry Broudy!) With a sabbatical looming, I submitted a research proposal in September 1975 for a Canada Council Leave Fellowship outlining my intention to examine the nature and value of open-mindedness and to explore the significance of this intellectual trait in the context of education. In the optimistic manner of research proposals, I concluded by saying that I hoped the research would lead to the publication of a book.

The first of several periods of sabbatical leave I have been fortunate to receive came in 1976. Sabbaticals have always been family adventures as well as academic retreats, and they have been a marvelous educational opportunity for our children. A memorable one later on in 1989 involved a term spent at the University of Sydney in Australia where two of our sons, Antony and Stephen, got a taste of school down under and visited a number of different countries on our round-the-world trip. My first sabbatical leave, however, in August 1976, took Niki, myself and our (then) two children, Andrew and Antony, to England where I was headed for the University of Hull to become reacquainted with Alan 
White. Few philosophers were his equal in the deployment of conceptual arguments in the manner of J.L. Austin, and his comments and suggestions on draft chapters at our weekly meetings were enormously helpful. At the end of my sabbatical, I returned to Dalhousie for my one and only foray into administration, serving as Chair of the Department of Education for a three-year term. I found time to revise my manuscript, and it was a red-letter day in 1979 when my first book appeared (Hare, 1979).

My main claim in Open-mindedness and Education is that open-mindedness involves a willingness to form and revise one's views as objectively and impartially as possible in the light of relevant considerations. This account captures, I believe, what is distinctive about those cases that are centrally representative of open-mindedness. The emphasis is on one's willingness, what Russell calls an inward readiness, to give weight to evidence and argument, genuinely trying to avoid bias and other factors that undermine one's efforts to arrive at true beliefs. The account makes clear, though some critics have missed this, that falling short of impartiality and objectivity is not sufficient to warrant the accusation of closed-mindedness (Hare, 1979, p. 79). The open-minded person is sincerely trying to be objective and impartial, but there is no suggestion, as Harvey Siegel brings out, that the open-minded person meets the high standard of epistemic competence reflected, for example, in the ideal of critical thinking (Siegel, 2009, p. 31).

Other accounts at the time portrayed open-mindedness as necessarily involving a neutral stance or a skeptical stance. The view I have defended consistently, contrary to what certain critics have claimed, is that open-mindedness is compatible with being fully confident that one's position is correct. The open-minded person will entertain doubts in the sense of listening to the criticisms and objections of others, but this does not mean having doubts of one's own (Hare, 1985, p. 32). Open-mindedness involves recognizing that there remains a permanent possibility of reopening issues (Hare, 1979, p. 30), and that knowledge claims remain revisable in the light of counter-evidence and counter-argument (Hare, 1979, p. 61).

I soon realized that I had been setting out the agenda for my next project. The final chapter of Open-mindedness and Education had defended the value of open-mindedness in education against a number of practical and philosophical objections. One critic observed that few people would deny that open-mindedness is an important aim of education, so a defence of the ideal was hardly called for. I set out over the next few years to explore this objection, presenting my views in a second book, In Defence of Open-mindedness (1985). Criticisms of open-mindedness seemed to be everywhere once I went looking for them, and I suspect that others failed to see them because they did not expect there to be any. I argue that open-mindedness is a desirable attitude with respect to scientific and ethical beliefs, and in such contexts as administration and elementary education, despite the many objections raised.

In the mid-1980s, I decided it was time to make good the deficiency in my background with respect to Bertrand Russell that had been nagging at me for some time. The catalyst was a meeting of the Canadian Philosophy of Education Society (CPES) to be held in 1987 at McMaster University, home of the Bertrand Russell Archives. This was the beginning of a long-term engagement with Russell's work, leading to a number of published articles. The immediate result was a paper presented at the McMaster conference and subsequently published (1987) in Russell. I challenged the standard view that Russell's work on educational ideas was not properly philosophical; and I identified Russell as a significant contributor to a tradition in philosophy of education, continued by Israel Scheffler and Harvey Siegel, that emphasizes the role of reasons in teaching. A footnote to the 1987 conference: I was startled to learn, on entering the room to give my paper, that Russell's daughter, Kate, was seated on the front row. I am happy to say that she was very gracious in her comments about my paper afterwards.

Reflection on Russell's views on teaching, combined with other work I was doing at the time on the notorious Keegstra affair in Alberta, prompted in me a renewed concern with the nature of good teaching and teacher education. The Keegstra case, of course, involved systematic and outright indoctrination (1990a), but beyond these concerns, popular conceptions of good teaching struck me as 
extremely narrow in their preoccupation with skills and techniques. At that point in my career, I had been involved in teacher education for twenty years, and I had become convinced that good teaching presupposes the possession of certain intellectual and moral virtues. I saw my task as following up on Socrates' query about the kind of person we would want to teach our own children to be and so in my What Makes a Good Teacher (1993), I set out to develop a rich and detailed philosophical account of eight central virtues. The argument I present is that humility, courage, impartiality, open-mindedness, empathy, enthusiasm, judgment, and imagination are the sort of qualities we should be trying to cultivate and encourage in teachers, moving beyond a narrow focus on particular strategies and approaches that often prove to be of merely fleeting interest.

My interest in the education of teachers explains my involvement in a number of projects aimed at developing materials that might help teachers take a critical and independent look at their own practice and at influential educational theories. In 1981, I edited a special issue of the Journal of Education (Nova Scotia) with contributions from philosophers and philosophers of education aimed primarily at practicing teachers (1981). Some years later (1990b), I produced an audio tape entitled Twentieth Century Philosophy of Education which contained short talks on Dewey (Jonas Soltis), Russell (myself), R.S. Peters (Robin Barrow), and Israel Scheffler (Harvey Siegel). In the early 1990s, John Portelli and I developed a book of case studies $\left(2003,3^{\text {rd }}\right.$ ed.) designed to encourage teachers to explore the complex issues that arise in their professional work, and to recognize the need to use their own critical judgment. We also collaborated on a book of readings $\left(2001,3^{\text {rd }}\right.$ ed.) in philosophy of education, aiming to include material that is philosophically strong but also related to issues that teachers today are likely to face. More recently, we put together a collection of short essays written by some forty leading philosophers of education exploring key questions in education (2007).

In all of these ventures, my concern has been to make philosophical ideas accessible and meaningful to teachers; and in my own teaching, I have continually looked for ways to help and encourage teachers to find their own voice and resist the inclination to allow fashionable ideas to constrain and diminish their own judgment.

I remain convinced that philosophy of education is vitally important and immensely useful for teachers. I have tried to offset the growing pressure to reduce teacher education to mere training; that way, as Dewey warned, lies intellectual subservience. To mark the millennium, I published an article (2000) showing how philosophers of education in the 20th century have helped us to think about teaching differently and, thereby, to teach in a different way. This was an opportunity to showcase a wide range of challenging ideas about teaching emerging from philosophy of education, and I drew on the work of philosophers throughout the century, from Dewey, Russell and Whitehead, to Scheffler, Passmore, and R.M. Hare, to Paulo Freire, Maxine Greene, Nel Noddings, and Jane Roland Martin. More recently, in my Helen DeVitt Jones Lecture at Texas Tech University entitled "Why philosophy for educators?", subsequently published (2007), I argue that there are numerous outcomes resulting from the study of philosophy that connect with good practice. Quite apart from its intrinsic interest, philosophy is of great practical value to teachers, principals, and educational administrators.

In 1995, the Nova Scotia government closed a number of teacher education programs in the province, including the one at Dalhousie University, in a vain attempt to reduce the number of teachers graduating each year. In fact, the number of teaching certificates granted in the province annually has remained constant as students who did not gain a place in one of the remaining teacher education programs in Nova Scotia simply headed to Maine to gain a teaching credential. What seemed at first a serious setback to my career turned instead into an unexpected and wonderful opportunity. I moved to Mount Saint Vincent University in Halifax and remained there until I retired in June, 2008. These proved to be the happiest years of my career, working with excellent colleagues and first-rate students in a very supportive university environment. I particularly enjoyed teaching in the Leadership program, supervising experienced teachers working on projects that bring philosophical ideas to bear on practice. Mount Saint Vincent University honoured me by hosting an international conference on the theme of 
open-mindedness and the intellectual virtues when I retired, and the proceedings appear in a special issue of Paideusis (2009).

My work on open-mindedness has continued throughout. In the 1990s, Terry McLaughlin and I joined forces (Hare and McLaughlin, 1994, 1998) to defend a shared conception of open-mindedness. It was a rare privilege for me to collaborate with one of the finest philosophers of education in the field. Terry's early death in 2006 was a huge loss. My more recent work on open-mindedness builds on my earlier inquiries and takes up a number of questions that have been insufficiently explored in the literature:

a) Does open-mindedness mean that we must give respectful consideration to pseudoscience, Holocaust denial, and conspiracy theories? I offer an account to explain when openmindedness is appropriate and what it requires (2009a).

b) How are we to avoid the trap of taking our own open-mindedness for granted? I have developed a set of guidelines to help turn the spotlight on our attitude towards our own beliefs (2004).

c) Should we encourage students to wonder if their teachers are open-minded? I defend Mill's view that the judgment of open-minded individuals invites a measure of confidence, and I suggest ways in which students might discover whether or not their teachers are genuinely open-minded (2007; cf. Sockett, 2009).

d) Are we right to think that open-mindedness is important? I have tried to show that if we can set aside muddled objections, a set of reasons can be developed revealing the merits and strengths of open-mindedness (2006).

All of these discussions help to provide a richer account of the ideal by grounding it in a wide variety of examples.

It has been gratifying over the past few years to see a resurgence of interest in the general philosophical community in open-mindedness and the intellectual virtues. There were times in the early years when I felt that I was crying in the wilderness and I hope that I have played a part in rekindling interest in this important virtue.

I have not been drawn to epistemological relativism or postmodernism. The despairing skepticism reflected in a range of views proclaiming that what is true is whatever seems true to an individual, that one interpretation of a text is no better than another, that self-serving biases exclude the possibility of objectivity, that science is no closer to the mark than myth, and so on, results from confusions and fallacies that have been amply exposed by philosophers such as Susan Haack, Nicholas Rescher, and Harvey Siegel. Bertrand Russell warned against thinking that we had found Truth, but Russell was not inclined to refer dismissively to 'truth' as if the whole enterprise of rational inquiry deserved scorn. My early intuition that truth and propaganda are quite different still seems sound. If the approximate truth that Russell thought possible is to be attained, however, we need to keep alive the very ideals — scholarly impartiality, respect for evidence, critical thinking, and open-mindedness-now clearly the object of derision in many quarters. Notwithstanding that one persistent confusion about open-mindedness is that it encourages or even amounts to a relativistic stance, the conception of openmindedness I have defended stands in the sharpest contrast to relativism.

My philosophical muse throughout has been Socrates. Mill was surely right to insist that we can hardly be too often reminded that there was once a philosopher called Socrates, and it is a great pity that many students complete high school, some even leave university, without becoming familiar with his life and work. After discovering that one of my own children had fortuitously encountered Plato's Apology in grade nine, I published an article (1986) urging teachers to introduce students to this work and allow them to glimpse ideas and a way of thinking that might otherwise remain hidden. I have found myself coming back time and again to Socrates for insights and inspiration (1993, 1995, 2009b), whether on teaching, wisdom, philosophical inquiry, or other matters. The Socratic principle that has 
influenced me more than any other is the one reflected in my title, that we must follow the argument where it leads. That, it seems to me, is itself a wonderfully succinct articulation of the ideal of openmindedness.

\section{References}

Hare, William. "Education Amid Cultural Diversity.” International Education 2.1 (1972): 36-44.

Hare, William. "Controversial Issues and the Teacher." High School Journal 57. 2 (1973): 51-60. Reprinted in Philosophy of Education: Canadian Perspectives. Eds. Donald B. Cochrane and Martin Schiralli. Don Mills: Collier-MacMillan, 1982: 242-249.

Hare, William. "The Concept of Discussion in Educational Theory." Kansas Studies in Education 23. 1 (1974): 6-12. Reprinted in a condensed version entitled "The Concept of Discussion." Education Digest 40.5 (1975): 28-31.

Hare, William. "Openness in Education." Thirtieth Annual Meeting of the Philosophy of Education Society. Ed. M.J. Parsons. 1974. 218-226.

Hare, William. "Has Listening Had a Fair Hearing?" Agora 3.1 (1975): 3-13.

Hare, William. Open-mindedness and Education. Montreal: McGill-Queen's University Press, 1979.

Hare, William. In Defence of Open-mindedness. Montreal: McGill-Queen's University Press, 1985.

Hare, William. "Reading the Apology in School." The Classical World 80.1 (1986): 25-29.

Hare, William. "Russell's Contribution to the Philosophy of Education." Russell: The Journal of the Bertrand Russell Arcbives 7.1 (1987): 25-41. Reprinted in Bertrand Russell: Critical Assessments, Vol. 4. Ed. A.D. Irvine. London: Routledge, 1998. 133-48.

Hare, William. "Limiting the Freedom of Expression: The Keegstra Case." Canadian Journal of Education 15.4 (1990a): 375-89.

Hare, William. Twentieth Century Philosophy of Education. Halifax: Dalhousie University, 1990b. Audio tape.

Hare, William. What Makes a Good Teacher: Reflections on Some Characteristics Central to the Educational Enterprise. London, ON: Althouse Press, 1993.

Hare, William. Teaching and the Socratic Virtues. Faculty of Education: Memorial University, 1995.

Hare, William. "Reason in Teaching: Scheffler's Philosophy of Education." Studies in Pbilosophy and Education 16.1 (1997): 89-101. Reprinted in Reason and Education: Essays in Honour of Israel Scheffler. Ed. Harvey Siegel. Dordrecht: Kluwer, 1997. 89-101.

Hare, William. "Reflections on the Teacher's Tasks: Contributions from Philosophy of Education in the Twentieth Century." Education Research and Perspectives 27 (2000): 1-23.

Hare, William. "R.M. Hare, 1919-2002”, Paideusis 14.2 (2001): 72-76.

Hare, William. “Assessing One’s Own Open-mindedness.” Philosophy Now 47 (2004): 26-28.

Hare, William. "John Passmore, 1914-2004.” Journal of Thought 40.2 (2005): 113-16.

Hare, William. "Why Open-mindedness Matters." Think 13 (2006): 7-15.

Hare, William. "Why Philosophy for Educators?" International Journal of Applied Philosophy 21.2 (2007a): 149-59.

Hare, William. "Credibility and Credulity: Monitoring Teachers for Trustworthiness." Journal of Philosophy of Education 41. 2 (2007b): 207-219.

Hare, William. "What Open-mindedness Requires.” Skeptical Inquirer 33.1 (2009a): 36-39.

Hare, William. "Socratic Open-mindedness.” Paideusis 18.1 (2009b): 5-16.

Hare, William, ed. Journal of Education (Nova Scotia) 7.2 (1981). Special issue on philosophy of education.

Hare, William, \& T.H. McLaughlin. “Open-mindedness, Commitment and Peter Gardner." Journal of Philosophy of Education 28.2 (1994): 239-44. 
Hare, William, \& T.H. McLaughlin. "Four Anxieties About Open-mindedness: Reassuring Peter Gardner." Journal of Philosophy of Education 32.2 (1998): 283-92.

Hare, William \& Portelli, J.P., eds. Philosophy of Education: Introductory Readings. 3rd ed. Calgary: Detselig Enterprises, 2001.

Hare, William \& Portelli, J.P. What to Do? Case Studies for Educators. Third revised edition. Halifax: Edphil Books, 2003.

Hare, William \& Portelli, J.P. Key Questions for Educators. San Francisco: Caddo Gap Press, 2007.

Paideusis 18.1. Special issue on open-mindedness and the virtues in education. Ed. M. Forrest, 2009.

Scheffler, Israel. The Language of Education, Springfield, IL: Charles C. Thomas, 1960.

Scheffler, Israel. Conditions of Knowledge: An Introduction to Epistemology and Education. Chicago: University of Chicago Press, 1978

Siegel, Harvey. "Open-mindedness, Critical Thinking, and Indoctrination: Homage to William Hare." Paideusis 18.1 (2009): 26-34.

Siegel, Harvey, ed. Reason and Education: Essays in Honor of Israel Scheffler. Dordrecht: Kluwer Academic Publishers, 1997.

Sockett, H. "Dispositions as Virtues: The Complexity of the Construct." Journal of Teacher Education 60,3 (2009): 291-303.

\section{Works That Have Significantly Influenced My Thinking}

Ayer, A.J. The Problem of Knowledge. Harmondsworth: Penguin Books, 1956.

Hare, R.M. The Language of Morals. Oxford: Clarendon Press, 1952.

Mill, J.S. On Liberty. 1859. Harmondsworth: Penguin Books, 1977.

Passmore, John. The Philosophy of Teaching. London: Duckworth, 1980.

Peters, R.S. Ethics and Education. London: George Allen and Unwin, 1966.

Plato. The Last Days of Socrates. Harmondsworth: Penguin Books, 1969.

Russell, Bertrand. The Problems of Philosophy. 1912. London: Oxford University Press, 1973.

Scheffler, Israel. The Language of Education. Springfield, IL: Charles C. Thomas, 1960.

Siegel, Harvey. Educating Reason. New York: Routledge, 1988.

White, Alan R. The Philosophy of Mind. New York: Random House, 1968. 